\title{
Antibodi Anti DS-DNA Sebagai Faktor Prognosis Mortalitas pada Lupus Eritematosus Sistemik
}

\author{
Muslikhah Yuni Farkhati, Sunartini Hapsara, Cahya Dewi Satria \\ Bagian Ilmu Kesehatan Anak Fakultas Kedokteran Universitas Gadjah Mada/RSUP Dr. Sardjito, \\ Yogyakarta
}

Latar belakang. Angka kejadian lupus eritematosus sistemik (LES) di RSUP Dr Sardjito meningkat dengan mortalitas tinggi. Antibodi anti double stranded-DNA (ds- DNA) merupakan antibodi patognomonik pada SLE.

Tujuan. Mengetahui hubungan antara antibodi anti ds-DNA dengan mortalitas pasien SLE.

Metode. Penelitian kohort retrospektif terhadap pasien SLE yang berusia kurang dari 18 tahun yang didapatkan secara konsekutif. Survival dihitung menggunakan metode Kaplan Meier. Analisis log rank dan regresi Cox digunakan untuk mengidentifikasi faktor yang berhubungan dengan mortalitas.

Hasil. Didapatkan 46 pasien ikutserta dalam penelitian, 8 (17,4\%) laki-laki dan 38 (82,6\%) perempuan dengan rerata usia terdiagnosis 11,9 tahun, 21 subyek $(45,7 \%)$ diantaranya meninggal. Survival pada tahun pertama, ketiga dan kelima adalah 85\%, 60\%, dan $30 \%$. Rerata waktu follow up pasien dengan antibodi anti ds-DNA sebesar 885,5 hari (IK 95\% 631,9-1139,1) tampak lebih pendek secara bermakna dibanding pasien dengan antibodi anti ds DNA negatif 4807,5 (IK 95\% 4025,4-5389,0). Analisis multivariat menunjukkan antibodi anti ds-DNA merupakan satu - satunya faktor prognostik terhadap mortalitas pasien SLE (hazard ratio 6,7 ; IK 95\% 1,38-12,40).

Kesimpulan. Antibodi anti ds-DNA merupakan faktor prognosis terhadap mortalitas pasien SLE.

Sari Pediatri 2012;14(2):90-6.

Kata kunci: antibodi anti ds-DNA, mortalitas, faktor prognosis

L

upus eritematosus sistemik (LES) merupakan penyakit autoimun yang bersifat sistemik. ${ }^{1}$ Selama lebih dari empat dekade angka kejadian LES meningkat tiga kali lipat dari

\footnotetext{
Alamat korespondensi:

Dr. Muslikhah Yuni Farkhati, Sp.A. Bagian Ilmu Kesehatan Anak, Fakultas Kedokteran Universitas Gadjah Mada/RSUP. Dr. Sardjito, Jalan Kesehatan No. 1 Sekip Yogyakarta 55284, Indonesia. Telp. (0274) 561616, Fax. (0274) 583745. E-mail: muslikhahyf@gmail.com
}

51/100.000 menjadi antara 122 sampai 124/100.000 penduduk di dunia. Di Bagian Ilmu Kesehatan Anak RSUP Dr Sardjito Yogyakarta terjadi peningkatan angka kejadian LES rata-rata 5-6 pasien per tahun dengan survival pada tahun kelima sebesar $65 \% .^{2}$ Rendahnya survival tersebut menimbulkan sebuah pertanyaan mengenai faktor-faktor yang berpengaruh terhadap luaran pasien LES.

Gangguan utama yang terjadi pada LES adalah pembentukan autoantibodi. Autoantibodi terhadap DNA ( anti-double stranded-DNA) dapat dijumpai 
pada lebih dari 75\% pasien. Telah diketahui bahwa titer antibodi antiDNA bervariasi sesuai waktu dan aktifitas penyakit. Selain itu terdapat hubungan yang kuat antara antibodi antiDNA dengan glomerulonefritis. ${ }^{3}$ Kejadian flare lebih tinggi pada pasien dengan kadar antibodi anti dsDNA tinggi dan persistensi dari autoantibodi, ini dapat terjadi beberapa tahun sebelum flare terjadi. Meskipun ikut berperan dalam diagnosis dan sebagai prediktor terhadap aktifitas penyakit LES, namun peranan terhadap angka survival masih diperdebatkan. ${ }^{4}$ Yee CS $\mathrm{dkk}^{5}$ dan Mirzayan ${ }^{6}$ menemukan bahwa kerusakan organ dan survival tidak berhubungan dengan ras, usia, kadar anti kardiolipin, anti-Ro, dan antibodi ds-DNA. Hasil berbeda ditunjukkan oleh temuan Toloza dkk, ${ }^{7}$ terdapat faktorfaktor yang berhubungan dengan perjalanan penyakit dan luaran dari LES sangat penting untuk tata laksana dan intervensi terapi.

\section{Metode}

Penelitian kohort retrospektif dilakukan di Bagian Anak RSUP Dr Sardjito Yogyakarta mulai tahun 2007-April 2012. Digunakan nilai risiko relatif antibodi anti dsDNA terhadap kematian sebesar 3,2, proporsi insiden efek pada kelompok faktor risiko $56 \%$, kesalahan tipe I 5\%, kesalahan tipe II 20\%, maka diambil sampel secara konsekutif 24 untuk masing-masing kelompok. Kriteria inklusi adalah pasien usia 0-18 tahun yang telah didiagnosis LES berdasar kriteria American College of Rheumatology (ACR) 1997 yang telah direvisi selama minimal satu tahun, kecuali pada kasus berat yaitu kasus dengan gejala yang mengancam jiwa dan orang tua menyatakan persetujuan untuk diikutsertakan dalam penelitian. Subyek dieksklusi apabila menderita penyakit kronis, keganasan, dan penyakit vaskular yang terdiagnosis sebelum diagnosis LES ditegakkan dan data rekam medis tidak lengkap.

Data mengenai usia, jenis kelamin, gambaran klinis, dan laboratorium saat terdiagnosis serta luaran yang terjadi diambil dari rekam medis. Pasien dikelompokkan sebagai LES berat apabila terdapat kondisi kegawatan seperti glomerulonefritis proliferatif difus, dengan hipertensi berat, serebritis lupus, vaskulitis nekrotik sistemik. Pemeriksaan kualitatif antibodi anti ds-DNA dilakukan secara imunofluoresen terhadap hemoflagelata dari Chritidia lucilae dengan metode ELISA pada saat penegakan diagnosis LES.

Penilaian luaran dilakukan sejak pasien didiagnosis LES sampai akhir penelitian atau sampai pasien dinyatakan meninggal dunia atau pasien hilang dari pengamatan. Kematian dipastikan dari surat keterangan yang dikeluarkan oleh dokter saat pasien dirawat, atau diperoleh informasi dari orang tua. Penyebab kematian adalah keadaan atau penyakit sebagai penyebab kematian langsung.

Data dianalisis dengan statistik menggunakan paket Stata 11. Data mengenai survival kumulatif dianalisis dengan metode aktuarial kurva Kaplan-Meier. Analisis log rank dilakukan untuk mengetahui perbedaan rerata waktu terjadinya mortalitas pada masing-masing variabel, dilanjutkan dengan dilakukan alisis multivariat dilakukan terhadap variabel yang mempunyai nilai $\mathrm{p}<0,25$ dalam analisis bivariat dan bermakna secara klinis dengan menggunakan analisis Regresi Cox. Tingkat kemaknaan adalah $\alpha 0,05$.

\section{Hasil}

Selama periode penelitian didapatkan 46 anak memenuhi kriteria inklusi, terdiri 24 subyek pasein LES dengan antibodi anti ds-DNA positif dan 22 subyek pasien LES dengan antibodi anti ds-DNA negatif. Tidak ada sampel yang dieksklusi dan seluruh sampel dapat diikutkan sampai akhir pengamatan. Subyek penelitian terdiri dari 38 perempuan $(82,6 \%)$ dan delapan laki-laki $(17,4 \%)$ dengan perbandingan antara keduanya 6,9:1. Kelompok usia pubertas tampak lebih dominan pada dua kelompok pengamatan dengan rerata usia 11,9 (SD 3,2) tahun (Tabel 1)

Tabel 2 menunjukkan bahwa pada saat diagnosis, nefritis $(76,1 \%)$, artritis $(67,4 \%)$, tes ANA positif $(63,1 \%)$, dan ulkus mulut $(60,1 \%)$ merupakan gejala dan tanda klinis yang paling sering muncul. Dari 46 subyek, 21 subyek (45,7\%) meninggal. Kurva Kaplan Meier menunjukkan bahwa survival kumulatif bertutut turut pada tahun pertama, ketiga, dan kelima 85\%, 60\%, dan $30 \%$. Rerata survival pasien LES 1903,0 (SD 458,8) hari (95\% IK 1003,7-2802,4). Penyebab kematian terbanyak adalah infeksi $(38,1 \%)$, sepsis $(28,6 \%)$, penyakit aktif $(23,8 \%)$, dan gagal ginjal $(9,5 \%)$.

Dari Gambar 1 terlihat bahwa sejak tahun pertama survival pada pasien dengan antibodi anti ds-DNA 
Tabel 1. Karakteristik dasar subyek penelitian

\begin{tabular}{lccc}
\hline Karakteristik & $\begin{array}{c}\text { Meninggal } \\
\mathrm{n}\end{array}$ & $\begin{array}{c}\text { Hidup } \\
\mathrm{n}\end{array}$ & $\begin{array}{c}\text { Total } \\
\mathrm{n}\end{array}$ \\
\hline Jenis kelamin & & & \\
$\quad$ Perempuan & 18 & 20 & 38 \\
$\quad$ Laki - laki & 3 & 5 & 8 \\
Usia & & 5 & 11 \\
$\quad$ Prepubertas & 6 & 20 & 35 \\
$\quad$ Pubertas & 15 & & \\
Derajat penyakit & & 3 & 15 \\
$\quad$ Berat & 12 & 22 & 31 \\
$\quad$ Tidak berat & 9 & & \\
Antibodi anti ds-DNA & & 7 & 24 \\
$\quad$ Positif & 17 & 18 & 22 \\
$\quad$ Negatif & 4 & & \\
\hline
\end{tabular}

Tabel 2. Karakteristik gejala klinis yang muncul pada saat diagnosis

\begin{tabular}{lccc}
\hline Gejala klinis & $\begin{array}{c}\text { Meninggal } \\
\mathrm{n}\end{array}$ & $\begin{array}{c}\text { Hidup } \\
\mathrm{n}\end{array}$ & $\begin{array}{c}\text { Total } \\
\mathrm{n}\end{array}$ \\
\hline Bercak malar & 11 & 13 & 24 \\
Bercak diskoid & 3 & 5 & 8 \\
Fotosensitivitas & 10 & 9 & 19 \\
Ulkus mulut & 16 & 10 & 26 \\
Artritis & 15 & 16 & 31 \\
Serositis & 10 & 5 & 15 \\
Nefritis & 15 & 20 & 35 \\
Gejala neurologi & 12 & 3 & 15 \\
Anemia & 15 & 12 & 27 \\
Leukopenia & 4 & 1 & 5 \\
Trombositopenia & 5 & 4 & 9 \\
Tes ANA positif & 13 & 16 & 29 \\
Tes antibodi anti ds-DNA positif & 17 & 7 & 24 \\
\hline
\end{tabular}

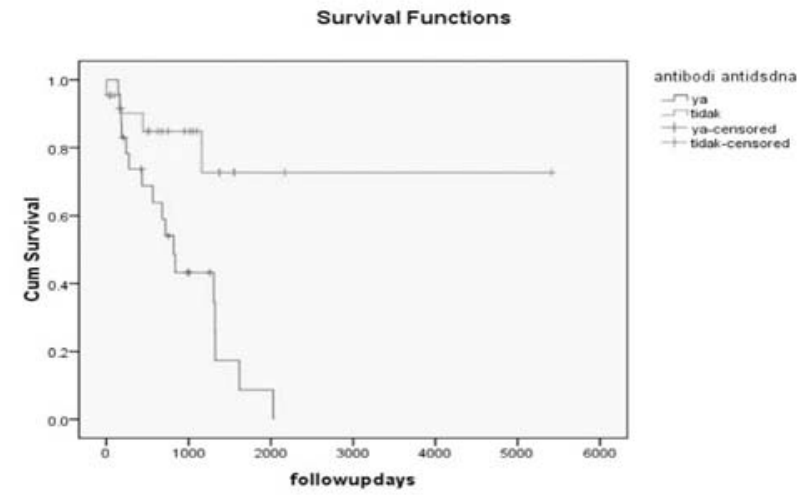

Gambar 1. Kurva Kaplan Meier survival berdasar antibodi anti ds-DNA positif $75 \%$, terlihat lebih rendah apabila dibandingkan dengan kelompok tanpa risiko 90\%. Hal tersebut terlihat sampai pengamatan tahun kelima.

Analisis survival menunjukkan bahwa pasien LES dengan antibodi anti ds-DNA positif mengalami mortalitas lebih cepat dibandingkan pasien dengan antibodi anti ds-DNA negatif. Rerata waktu follow $u p$ pasien dengan antibodi anti ds-DNA 885,5 hari (IK 95\% 631,9-1139,1) tampak lebih pendek secara bermakna dibandingkan pasien dengan antibodi anti ds DNA negatif 4807,5 (IK95\% 4025,4-5389,0) dengan $\mathrm{p}<0,001$. Pasien dengan derajat penyakit LES berat tampak mengalami mortalitas yang lebih cepat apabila dibandingkan dengan kelompok dengan derajat penyakit LES tidak berat $(\mathrm{p}<0,02)$. 
Tabel 3. Perbedaan survival pasien SLE berdasar karakteristik dasar subyek

\begin{tabular}{lccc}
\hline Karakteristik & $\begin{array}{c}\text { Rerata lama survival } \\
\text { (hari) }\end{array}$ & IK 95\% & $\mathrm{p}$ \\
\hline Jenis kelamin & & & \\
$\quad$ Perempuan & $19,962,0$ & $1022,1-2901,1$ & 0,46 \\
Laki - laki & 694,9 & $424,9-964,7$ & \\
Usia ( bulan ) & & & \\
$\quad 60-120$ & 1783,0 & $43,7-3522,3$ & 0,27 \\
$\quad>120$ & 1308,5 & $1029,8-1587,1$ & \\
Antibodi anti ds DNA & & & \\
$\quad$ Positif & 885,5 & $631,9-1139,1$ & $<0,01$ \\
$\quad$ Negatif & 4807,5 & $4025,4-5389,0$ & \\
Derajat penyakit & & & \\
$\quad$ Berat & 785,3 & $468,7-1102,9$ & 0,02 \\
$\quad$ Tidak berat & 2843,2 & $1363,3-4323,2$ & \\
Trombositopenia & & & \\
$\quad$ Ya & 820,1 & $390,2-1250,1$ & 0,21 \\
Tidak & 2069,1 & $1057,5-3080,7$ & \\
\hline
\end{tabular}

Tabel 4. Analisis bivariat faktor berpengaruh terhadap mortalitas

\begin{tabular}{lccc}
\hline Karakteristik & Risiko relatif (RR) & IK 95\% & $\mathrm{p}$ \\
\hline Jenis kelamin & 1,53 & $0,41-6,25$ & 0,37 \\
Usia (bulan) & 1,61 & $0,31-7,19$ & 0,45 \\
Antibodi anti ds DNA & 10,92 & $2,72-14,1$ & $<0,001$ \\
Derajat penyakit & 9,78 & $2,22-13,1$ & 0,001 \\
Trombositopenia & 1,64 & $0,38-7,1$ & 0,21 \\
\hline
\end{tabular}

Tabel 5. Hasil analisis multivariat faktor berpengaruh terhadap mortalitas pasien LES

\begin{tabular}{lccc}
\hline Variabel & HR & IK 95\% & p \\
\hline Jenis kelamin & 0,78 & $0,21-2,66$ & 0,62 \\
Usia terdiagnosis & 2,19 & $0,78-6,11$ & 0,25 \\
Antibodi anti ds-DNA & 2,94 & $1,1-8,7$ & 0,04 \\
Derajat penyakit & 2,11 & $0,56-7,9$ & 0,27 \\
Trombositopenia & 2,35 & $0,72-7,64$ & 0.16 \\
\hline
\end{tabular}

Analisis multivariat menunjukkan bahwa antibodi anti ds-DNA merupakan satu-satunya faktor prognostik terhadap mortalitas pasien LES. Pasien LES dengan antibodi anti ds-DNA positif mempunyai kemungkinan 2,94 kali lebih cepat untuk mengalami kematian dibandingkan dengan pasien LES dengan antibodi anti ds-DNA negatif (HR 2,94;IK95\% 1,1-8,7).

Analisis bivariat menunjukkan bahwa pasien dengan antibodi anti ds-DNA positif mempunyai risiko 10,92 kali (RR 10,92;IK95\% 2,72-14,1) untuk mengalami mortalitas dibandingkan dengan pasien dengan antibodi anti ds-DNA negatif. Selain itu terlihat bahwa derajat penyakit secara bermakna juga berpengaruh terhadap mortalitas (RR 9,78;IK 95\% 2,22-13,1). Meskipun pada analisis bivariat variabel jenis kelamin dan usia saat terdiagnosis mempunyai $\mathrm{p}>0,25$ tetapi karena mempunyai pengaruh yang bermakna dalam klinis maka kedua variabel tersebut tetap diikutsertakan dalam analisis multivariat (Tabel 5). 


\section{Pembahasan}

Gambaran epidemiologi pada penelitian kami terlihat mempunyai kesamaan dengan penelitian terdahulu. Perbandingan perempuan dan laki- laki 6,9:1, terlihat sama dengan beberapa penelitian lain yaitu berkisar antara 5:1 sampai 10:1. ${ }^{9}$ Penelitian yang dilakukan Agarwal ${ }^{10}$ menunjukkan bahwa pada kelompok usia 0-9 tahun terdapat perbandingan perempuan dengan laki-laki 4:3, kelompok 10-14 tahun 4:1, dan 15-19 tahun 5:1. Pada penelitian kami rerata usia saat terdiagnosis adalah 11,9 tahun, mendukung bukti tentang kemungkinan peranan hormonal dalam terjadinya LES. ${ }^{9}$

Manifestasi gejala klinis paling banyak muncul pada saat terdiagnosis adalah nefritis, artritis, dan ulkus mulut sesuai dengan penelitian yang dilakukan oleh Houman. ${ }^{8}$ Hasil yang sama juga ditunjukkan oleh Sandra ${ }^{11}$ dan Mook ${ }^{12}$ dengan gejala nefritis yang muncul berkisar 45\%-60\%. Penegakkan kelainan ginjal pada penelitian kami didasarkan pada gambaran klinis, tanpa dilakukan biopsi sesuai dengan klasifikasi WHO. Hasil tes ANA positif ditemukan pada $63,1 \%$ subyek, menyerupai penelitian yang dilakukan oleh Mok dkk. ${ }^{12}$ Meskipun merupakan pemeriksaan dengan sensitifitas cukup tinggi untuk LES (92\%) namun tes ANA mempunyai spesifisitas rendah (63\%) karena dapat ditemukan pada anak normal dan penyakit rheumatoid yang lain. Hal tersebut dapat menjelaskan bahwa kemaknaan secara klinis dan pengaruh tes ANA terhadap perjalanan penyakit LES tidak besar.

Kelainan neurologi terjadi pada 35,6\% subyek dengan $80 \%$ di antaranya mengalami kematian. Beberapa penelitian terdahulu menunjukkan bahwa keterlibatan sistem susunan saraf pusat (SSP) dapat terjadi pada $15 \%-45 \%$ pasien dan merupakan prediktor mortalitas dan morbiditas yang berat pada pasien LES. ${ }^{1 .}$ Mikdashi ${ }^{14}$ menemukan bahwa kadar antibodi anti ds-DNA, antibodi antikardiolipin $(\mathrm{aCL})$ dan antikoagulan lupus yang tinggi dapat menimbulkan reaksi inflamasi dan vaskulitis pada jaringan SSP. Kemungkinan penyebab yang dapat dipertimbangkan ikut berperan terhadap kematian yang tinggi dalam penelitian kami karena tidak semua pasien dengan kelainan neurologi mendapat terapi sesuai protokol LES berat dengan menggunakan regimen immunoglobulin intraven (IVIG) karena masalah biaya.
Survival total pasien pada tahun pertama, ketiga, dan kelima berturut turut 85\%, 65\%, dan 30\% terlihat lebih rendah dibandingkan dengan penelitian yang dilakukan di tempat lain. Survival di Eropa dan Amerika pada tahun kelima, sepuluh, dan lima belas berturut turut $90 \%$, 85\%, dan $80 \% \cdot{ }^{15-17}$ Hasil yang bervariasi ditemukan dari penelitian yang dilakukan di Asia. Selama tahun 1980-2003 angka survival pada tahun kelima lebih dari 90\% hanya didapatkan di Cina dan Korea, sedangkan di negara lain berkisar 75\%-88\%. ${ }^{11}$ Demikian pula dengan penelitian terhadap pasien LES di Afrika menunjukkan survival $75 \%$ pada tahun kelima. ${ }^{18}$ Penyakit LES terbukti mempunyai perjalanan penyakit yang lebih agresif pada ras kulit hitam dan Asia. Hal tersebut berhubungan polimorfisme gen FcyRIIA dan mutasi pada kodon 54 dari gen penyandi MBL yang mengakibatkan kerentanan dan progesifitas penyakit. ${ }^{3,19}$

Pasien dengan anti ds DNA positif dan derajat penyakit berat terbukti mengalami mortalitas lebih cepat. Rerata pasien dengan antibodi anti ds-DNA positif mengalami mortalitas dalam waktu 2,11 (SD $0,83)$ tahun. Peneliti tidak mengidentifikasi kondisi sosioekonomi dan geografi, faktor budaya, dan fasilitas kesehatan yang ikut berperan terhadap kemungkinan keterlambatan diagnosis dan terapi yang tidak adekuat.

Seperti di negara lain, infeksi $(38,1 \%)$ merupakan penyebab kematian terbanyak bagi pasien LES diikuti oleh penyakit aktif $(23,8 \%)$ dan sepsis. Rabbani ${ }^{1}$ dalam penelitiannya menyimpulkan bahwa infeksi berhubungan kuat dengan mortalitas pasien LES, meskipun dirawat di ruang intensif. Pasien dengan LES mempunyai risiko tinggi terkena infeksi disebabkan selain karena faktor intrinsik yaitu abnormalitas komplemen, limfopenia, dan beratnya penyakit aktif juga karena terapi imunosupresif yang diperoleh. Penggunaan kortikosteroid dosis tinggi selama lebih dari satu bulan ditambah terapi dengan siklofosfamid terbukti meningkatkan 3,5 kali risiko terjadinya infeksi. ${ }^{20}$ Kematian yang disebabkan karena infeksi terutama terjadi pada masa rumatan, ditandai dengan rendahnya angka limfosit absolut. ${ }^{21}$

Analisis multivariat yang dilakukan pada penelitian kami memperlihatkan hasil bahwa antibodi anti dsDNA menjadi faktor prognostik yang penting terhadap kejadian mortalitas pasien LES, sesuai dengan hasil penelitian oleh Manger dkk dengan rasio hazard 1,6 (IK95\% 1,1-2,53) dalam penelitian yang dilakukan di 
Jerman terhadap pasien LES usia 14-67 tahun. Namun hasil yang berbeda ditunjukkan dalam penelitian lain yang dilakukan oleh Wadee, ${ }^{6}$ Mirzayan, ${ }^{8}$ dan Houfman. ${ }^{18}$

Antibodi anti ds-DNA telah lama dikaitkan dengan inflamasi dan kerusakan jaringan. ${ }^{2}$ Antibodi terhadap DNA tidak berikatan dengan naked DNA tetapi terikat pada nukleosom yang terdiri dari DNA yang diselubungi oleh kumparan protein histon (pasangan $\mathrm{H} 2 \mathrm{~A}, \mathrm{H} 2 \mathrm{~B}, \mathrm{H} 3$, dan $\mathrm{H} 4$ ). Protein histon $\mathrm{H} 1$ berfungsi sebagai penghubung antar kumparan. Dalam keadaan normal, nukleosom akan dikeluarkan selama apoptosis. Penelitian menunjukkan bahwa terdapat kegagalan uptake sel yang mengalami apoptosis ke dalam sel makrofag pada pasien LES yang memproduksi antibodi anti dsDNA. Patogenisitas antibodi ini tergantung pada kemampuannya merekrut sel-sel inflamasi melalui reseptor IgG Fc dan aktivasi komplemen. ${ }^{13}$ Selain di ginjal antibodi anti ds-DNA mempunyai kemampuan untuk berikatan dengan protein pada berbagai organ dapat berperan dalam terjadinya mortalitas. ${ }^{6,23}$

Hubungan antara kadar antibodi anti ds-DNA dengan aktifitas penyakit telah dibuktikan pada banyak penelitian. ${ }^{24}$ Dalam penelitian kohort prospektif terhadap pasien LES usia 10-48 tahun menunjukkan bahwa didapatkan peningkatan kadar antibodi anti dsDNA lebih dari $30 \mathrm{IU} / \mathrm{ml}$ dalam serum pada saat terjadi flare yang ditandai dengan peningkatan skor SLEDAI. Selain itu dalam penelitian tersebut juga disebutkan bahwa kombinasi peningkatan kadar antibodi anti ds-DNA dan antibodi terhadap komplemen (anti C1q) merupakan faktor risiko yang penting terhadap aktifitas penyakit dan luaran yang buruk (OR 8,0; IK95\% 1,19-62,5) Telah diketahui bahwa antibodi anti dsDNA dapat dideteksi sebelum gejala klinis muncul dan setelah gejala klinis mereda, sehingga variasi peningkatan kadar secara kuantitatif secara serial sangat bermanfaat dalam kebijakan pemberian terapi. ${ }^{4}$ Dalam penelitian prospektif lain dengan populasi pasien LES usia 7-45 tahun, Guilermo ${ }^{25}$ membuktikan bahwa semakin sering terjadi flare, semakin besar kemungkinan pasien tersebut mengalami mortalitas (OR 2,45; IK 95\% 1,98- 7,32) dan survival pada tahun kelima lebih tinggi pada pasien dengan flare yang lebih jarang (91\% vs $67 \%) .4,26$

Metode penelitian yang bersifat retrospektif menjadi salah satu kelemahan. Recall bias dapat terjadi karena tidak semua data mengenai perjalanan dan perkembangan penyakit tercatat dengan baik dalam rekam medis. Antibodi anti ds- DNA dilakukan secara kualitatif pada saat penegakan diagnosis saja sehingga tidak bisa digunakan untuk menilai aktifitas penyakit. Kelemahan yang lain adalah dasar penegakan diagnosis kelainan ginjal hanya dilakukan secara klinis, tanpa ditunjang dengan biopsi. Selection bias yang terjadi disebabkan karena penelitian kami berbasis rumah sakit, sehingga kasus yang muncul sebagian besar kasus rujukan dengan kondisi yang sudah buruk. Sebuah penelitian prospektif yang berkesinambungan untuk melanjutkan penelitian kami sangat diperlukan. Disimpulkan bahwa pasien LES dengan antibodi anti ds-DNA positif pada saat penegakan diagnosis mempunyai mortalitas lebih buruk dibanding pasien dengan antibodi anti ds-DNA negatif.

\section{Daftar pustaka}

1. Rabbani MA, Habib HB, Islam M, Ahmad B, Majid S, Shah SMA. Survival analysis and prognostic indicator of systemic lupus erythematosus in Pakistani patients. Lupus 2009; 18:848-55.

2. Farkhati MY, Sunartini_Hapsara, Satria CD. Survival and prognostic factors of systemic lupus erythematosus. Proceedings of Congress of Indonesian Pediatrics Society: 2011:236-42.

3. Mok CC, Lau CS. Pathogenesis of systemic lupus erythematosus. J Clin Pathol 2003;56:481-90.

4. Swaak AJG, Nossent JC, Smeenk RJT. Prognostic factors in systemic lupus erythematosus. Rheumatol Int 1999;11:127-32.

5. Yee CS, Hussein H, Skan J, Bowman S, Situnayake D, Gordon C. Association of damage with autoantibody profile, age, race, sex and disease duration in systemic lupus erythematosus. Rheumatol 2003;42:276-9.

6. Mirzayan MJ, Schmidt RE, Witte T. Prognostic parameters for flare in systemic lupus erythematosus. Rheumatol 2000;39:1316-9.

7. Toloza SA, Roseman JM, Alarcon GS, McGwin G,Uribe AG, Fessler BJ, dkk. Systemic lupus erythematosus in a multiethnic US cohort (LUMINA): Predictors of time to occurrence of initial damage. Arthritis \& Rheumatism 2004;50:3177-86.

8. Houman MH, Smiti-Khanfir M, Ghorbell IB, Miled M. Systemic lupus erythematosus in Tunisia: demographic clinical analysis of 100 patients. Lupus.2004;13:20411 
9. Akib AAP, Soepriadi M, Setiabudiawan B. Lupus Eritematosus Sistemik dalam Buku Ajar Alergi Imunologi. Edisi ke-2. Jakarta: Badan Penerbit Ikatan Dokter Anak Indoneia; 2007.h.346-73.

10. Agarwal I, Kumar T S, Ranjini K, Kirubakaran C, Danda C. Clinical features and outcome of systemic lupus erythematosus. Indian Pediatr 2009;46:711-4.

11. Sandra VN, King JO. An overview of clinical manifestation and survival of lupus erythematosus patients in Asia. APLAR J Rheumatol 2006; 9:336-41.

12. Mok CC, Lee KW, Ho CTK, Lau CS, Wong RWS. A prospective study of survival and prognostic indicators of systemic lupus erythematosus in a southern Chinese population. Rheumatol 2000;39:399-406.

13. Isenberg DA, Manson JJ, Ehrenstein MR, Rahman A. Fifty years of anti-dsDNA antibodies: are we approaching journey's end? . Rheumatol 2007;46:1056-6.

14. Mikdashi J, Handwerger B. Predictors of neuropsychiatric damage in systemic lupus erythematosus : data from Maryland lupus cohort. Rheumatol 2004;43:1555-60.

15. Blanco FJ, de la Mata J, Corrales A, Rodriguez-Valverde V, Rosas JC de La Camara AG. Survival Analysis of 306 European Spanish patients with systemic lupus erythematosus. Lupus 2008 ;7:159-63.

16. Fernandez M, Alarcon GS, Apte M, Andrade RM, Vila LM, Reville JD. Systemic lupus erythematosus in multiethnic US cohort XLIII. the significance of thrombocytopenia as a prognostic factor. Arthritis \& Rheumatism 2007;56:614-21.

17. Brugos B, Kiss E, Szodoray P, Szegedi G, Zeher M. Retrospective analysis of patients with lupus nephritis: data from a large clinical immunological canter in Hungary . Scandinavian J Immunol 2006;64:433-37.

18. Wadee S, Tikly M, Hopley M. Causes and predictors of death in South Africans with systemic lupus erythematosus. Rheumatol 2007;46:1487-91.

19. Crow MK. Collaboration of genetic association and lupus erythematosus. N Engl J Med 2008;28:956-8.

20. Ng WL, Chu CM, Wu AK, dkk. Lymphopenia at presentation is associated with increased risk of infection in patients with systemic lupus erythematosus.QJM 2005;99:47-8.

21. Morton M, Edmonds S, Doherty AM, Dhayjude A, Helbert M, Venning M. Factors associated with major infections in patients with granulomatosis with polyangiitis and systemic lupus erythematosus treated for deep organ involvement. Rheumatol Int 2011;4:5160.

22. Mortensen ES dan Rekvig OP. Nephritogenic potential of anti-DNA antibodies against necrotic nucleosomes. J Am Soc Nephrol 2009;20:696-704.

23. Yung S, Chan MT. Anti-DNA antibodies in the pathogenesis of lupus nephritis-The emerging mechanisms. Autoimmunity Review 2008;7: 317-21.

24. El- Hewala A, Nageeb GS, El-Shahawy EE, Sharaf DM, Omran AA EL Massalamy EF dkk. Anti-C1q and antids DNA antibodies in systemic lupus erythematosus : relationship with disease activity and renal involvement in Sharkia governorate, Egypt. The Egyptin Rheumatologist 2011;33:203-8.

25. Guilermo J, Alarcon GS, Scofield L, Reinlib L, Cooper GS. Understanding the epidemiology and progression of systemic lupus erythematosus. Semin Arthritits Rheum 2010;39:257-9.

26. Manger K, Manger B, Repp R, Geisselbrecht M, Geiger A, Pfahlberg A, dkk. Definition of risk factors for death, end stage renal disease and thromboembolic events in a monocentric cohort of 338 patients with systemic lupus erythematosus. Ann Rheum Dis 2002;61:1065-70. 